\title{
Near-shore distribution of phyllosomas of the two only lobster species (Decapoda: Achelata) present in Robinson Crusoe Island and endemic to the Juan Fernández archipelago
}

\author{
Distribución costera de filosomas de las dos únicas especies de langostas \\ (Decapoda: Achelata) presentes en la Isla Robinson Crusoe y endémicas del \\ archipiélago de Juan Fernández
}

\begin{abstract}
ÁLVARO T. PALMA*, ISMAEL CÁCERES-MONTENEGRO, RICHARD S. BENNETT, SPARTACO MAGNOLFI, LUIS A. HENRÍQUEZ, JORGE F. GUERRA, KAREN MANRÍQUEZ \& R. EDUARDO PALMA

Departamento de Ecología, Pontificia Universidad Católica de Chile and Center for Advanced Studies in Ecology and Biodiversity (CASEB), Alameda 340, Casilla 114-D, Santiago, Chile

*Corresponding author: apalma@bio.puc.cl
\end{abstract}

\begin{abstract}
Two lobster species coexist in the southeast Pacific Juan Fernández archipelago, Jasus frontalis (Milne-Edwards, 1837) and Acantharctus delfini (Bouvier, 1909). Like most lobster species they undergo a prolonged larval period, which is particularly long for J. frontalis (> 16 months). Though typical of Palinurids, this long larval duration is usually not thought to be conducive to local recruitment. While it is known that settlement is confined to the three islands of the archipelago (Robinson Crusoe, Alejandro Selkirk and Santa Clara) and Desventuradas Islands (aprox. $800 \mathrm{~km}$ to the north), it remains poorly understood how local larval supply allows such distribution pattern. The goal of this study is twofold. Firstly, we aimed to characterize the distribution and abundance of the larvae of these two species around Robinson Crusoe Island using plankton tows and systematic hydrographic records between October 2008 to March of 2011, thus providing the first systematic and prolonged coupled biophysical observations in the nearshore of the archipelago. We hypothesize that spatial and temporal larval distribution patterns are associated to their retention around the archipelago, thus contributing to our knowledge of the physical and biological processes maintaining their extreme isolation. Secondly, using molecular genetics, we confirm a simple taxonomic criteria to distinguish the larvae of the two species, thus aiding future studies of larval dynamics. Throughout phyllosomas of $A$. delfini were more abundant than that of $J$. frontalis. Both species were more abundant on the northern shores of Robinson Crusoe Island and generally associated with warmer and saltier waters and mostly present in the samples collected during spring and summer months. Phyllosomas of both species were more abundant during nighttime tows in the upper layer of the water column surveyed suggesting a diurnal vertical migration behavior which, for coastal dwelling meroplanktonic species, can be related to a nearshore larval retention mechanism. These preliminary results represent a pioneering effort to understand the mechanisms driving the endemism and extreme isolation of the two study species.
\end{abstract}

Key words: endemism, lobsters, oceanic island, phyllosoma.

\section{RESUMEN}

En el archipiélago de Juan Fernández en el Pacífico sur oriental coexisten dos especies de langostas, Jasus frontalis (Milne-Edwards, 1837) y Acantharctus delfini (Bouvier, 1909). Igual que la mayoría de las especies de langostas estas atraviesan por un prolongado período larval, el cual es particularmente largo para J. frontalis ( $>16$ meses). Aunque típico de los Palinúridos, esta prolongada duración larval por lo general no debiese conducir a un reclutamiento local. Si bien es sabido que el asentamiento se encuentra confinado a las tres islas que componen el archipiélago (Robinson Crusoe, Alejandro Selkirk y Santa Clara) e Islas Desventuradas (aprox. $600 \mathrm{~km}$ al norte), el conocimiento acerca de cómo el abastecimiento local, a través del asentamiento y reclutamiento permite tal patrón de distribución, es escaso. El objetivo de este estudio es doble. En primer lugar, caracterizar la distribución y abundancia de las larvas de estas dos especies alrededor de la isla Robinson Crusoe mediante muestreos de plancton y registros hidrográficos entre octubre de 2008 y marzo de 2011, generando de este modo la primera observación sistemática y prolongada en el archipiélago del acople biofísico cercano a la costa. Hipotetizamos que los patrones de distribución espacial y temporal de las larvas están asociados con su retención alrededor del archipiélago, contribuyendo de este modo con el conocimiento de los procesos físicos y biológicos que mantienen su aislamiento extremo. En segundo lugar, mediante el uso de genética molecular, confirmamos un criterio taxonómico simple para distinguir las larvas de ambas especies, contribuyendo así con futuros estudios sobre dinámica de larvas. En general las filosomas de A. delfini fueron más abundantes que las de J. frontalis. La abundancia de ambas especies fue mayor en los sitios del lado norte de la isla Robinson Crusoe y por lo general asociadas con aguas cálidas y saladas observadas durante los meses de primavera y verano. Las filosomas de ambas especies fueron más abundantes en las capas superiores de la columna de agua y obtenidas durante los muestreos nocturnos, lo que sugiere un comportamiento de migración vertical que, para especies costeras meroplanctónicas, puede relacionarse con un mecanismo de retención larval. Estos resultados preliminares representan un esfuerzo pionero para entender los mecanismos asociados con el endemismos y aislamiento extremo de las dos especies estudiadas.

Palabras clave: endemismo, filosomas, islas oceánicas, langostas. 


\section{INTRODUCTION}

The duration of the planktonic phase is usually related with the degree of dispersive capabilities and to what extent larvae represent the connection among otherwise isolated benthic stages of many marine invertebrates (Scheltema 1975, Eckert 2003). Despite previous work that has emphasized the extensive dispersal potential of larvae (e.g., Scheltema 1986, Shanks et al. 2003), recent publications also point to the extraordinary extent to which these larvae succeed in returning to their place of origin (Cowen et al. 2000, Cowen 2002, Mora \& Sale 2002, Paris \& Cowen 2004, Cowen et al. 2006, Steneck 2006). The planktonic larval period of benthic species is highly variable; on the order of minutes for coral species (Carlon \& Olson 1993), days for reef fishes (Forrester 1995), weeks for barnacles (Minchinton \& Scheibling 1991) and American lobster (Incze et al. 2000), weeks to months for crabs (Wing et al. 1995, Palma et al. 2006), and months to more than one year for some spiny lobsters (Booth \& Phillips 1994).

Hence, the study of species with rather long larval duration periods, yet with restricted geographic distribution, represents a rather unique opportunity to understand about the mechanisms responsible for such isolation. This is the case of the Palinurid Jasus frontalis (MilneEdwards, 1837)and the Scyllarid Acantharctus delfini (Bouvier, 1909), two lobster species endemic to a small group of islands in the south east Pacific (Robinson Crusoe, Alejandro Selkirk and Desventuradas Islands) off the coast of Chile. Most Palinurids for which data exist have estimated larval duration in nature of 6-12 months (but longer for Jasus spp. - up to 24 months, Bruce et al. 2000, Inoue et al. 2001, Phillips et al. 2006). Among Scyllarids, however, there is a wider range of estimated larval lifespan, from one to at least nine months (Inoue et al. 2001, Booth et al. 2005, Phillips et al. 2006). Additionally, it has been suggested that small-size adult Scyllarid species, such as $A$. delfini are likely to have a brief inshore development (Phillips et al. 2006). Such marked difference in larval duration is consistent with differences in the theoretical range of phyllosoma dispersal. While Palinurids have the potential for broad geographic dispersal, Scyllarids are expected to remain within a much more restricted area during their larval phase (Coutures 2000, Inoue et al. 2001).
The series of small islands, inhabited by these lobster species, represent abrupt promontories that emerge from great depths between the west side of the oceanic branch of the Humboldt current system and the subtropical Pacific influence zone along the centralnorth coast of continental Chile (Vergara \& Morales 1985). A large feature affecting this area of the south-east Pacific corresponds to a large anticyclonic system where three main water types can be distinguished; a subtropical surface layer on top of an intermediate Antarctic water and deep Pacific water along the bottom (Parin et al. 1997). The surface layer around this island system is also characterized by the presence of a permanent thermocline between 100 and $300 \mathrm{~m}$ (Moraga \& Argandoña 2008). The oceanic circulation in this zone is composed by two flows in opposite directions; the northward cold flow influenced by the oceanic branch of the Humboldt system during winter months and the southward warm flow influenced by the subsurface equatorial water during summer months (Fuenzalida et al. 2007).

In addition to being endemic to these few small islands, the spiny lobster $J$. frontalis represents an important economic resource that has been locally exploited since 1893 (Martínez \& Boré 1980). This is the main reason that has stimulated numerous studies related to the fishery of this species, which have mainly considered the larger individuals of the population (Arana \& Melo 1973, Arana 1985, Yañez et al. 1985, Arana 1987, Arana \& Vega 2000). Notwithstanding these studies, it is surprising how little is known about some basic aspects of its ecology. As part of these unknowns, is the lack of information regarding its larval ecology. Fewer, and rather descriptive studies, have documented the presence of some of the larval stages of these species around this island system with presence of a variable number of larvae only from few plankton tows performed near the islands (Rivera \& Mujica 2004, Mujica 2006). Like findings from other island settings, the existence of endemic species around isolated oceanic islands suggests successful retention, through the interplay between physical and biological processes (Cowen et al. 2000, Robertson 2001). It is obvious that the highly restricted $J$. frontalis has been able to self-sustain their populations even in the face of historical exploitation pressure. Although A. delfini 
appears to share the same geographic range and endemism status (Holthuis 2002), much less is known about its ecology, likely due to its lack of commercial value.

The goal of this study is to characterize the distribution and abundance of the larvae of these two species, which we hypothesize are displaying distribution patterns that may lead to their retention within this island system. We addressed this through systematic nearshore plankton collections at different spatial and temporal scales around Robinson Crusoe Island, together with the recordings of basic hydrographic information over the span of several seasons.

\section{METHODS}

\section{Study sites and plankton surveys}

For this study we performed plankton tows from October 2008 to March of 2011, at different frequencies (depending on weather conditions and logistic feasibilities), along several sites around Robinson Crusoe Island $\left(33^{\circ} 37^{\prime} \mathrm{S} ; 80^{\circ} 00^{\prime} \mathrm{W}\right)$ in the Juan Fernández archipelago. At five roughly equidistant sites around the island, transects (ca. $1.5 \mathrm{~km} \mathrm{long}$ ) running parallel to the coast, were surveyed (Fig. 1). These five sites were visited simultaneously only in five occasions (Table 1). On each occasion samples were obtained, on board of R/V Poli, using two types of simultaneously towed plankton nets. Surface samples were collected using a floating epineustonic net with a $1.2 \times 0.5 \mathrm{~m}$ rectangular opening and floating frame with a $210 \mu \mathrm{m}$ mesh size (see DiSalvo 1988), while 10

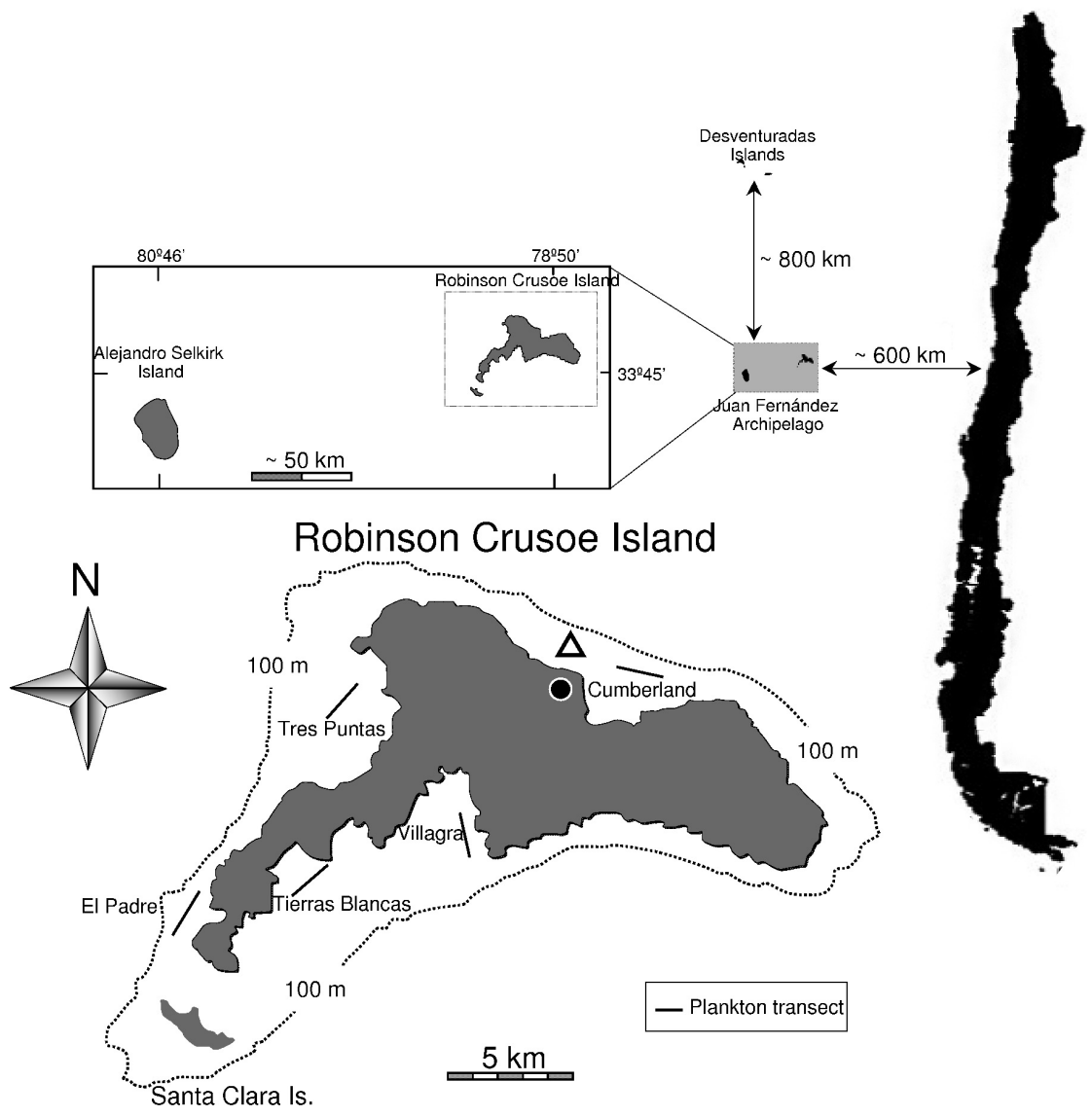

Fig. 1: Map showing the location of the Juan Fernández archipelago (Robinson Crusoe, Santa Clara and Alejandro Selkirk Islands) and the Desventuradas Islands to the north. The position of plankton transects is provided for each site around Robinson Crusoe Island. The triangle signals the location of the mooring system with current meters and the black circle the location of the weather station.

Mapa que muestra la ubicación del archipiélago de Juan Fernández (islas Robinson Crusoe, Santa Clara y Alejandro Selkirk) e Islas Desventuradas hacia el norte. La posición de los transectos de plankton se muestra para cada sitio alrededor de la Isla Robinson Crusoe. El triángulo indica la ubicación del sistema de fondeo con los correntómetros y el círculo negro la ubicación de la estación meteorológica. 
m-depth samples were obtained with a bongo circular opening net $(60 \mathrm{~cm}$ in diameter) with a $210 \mu \mathrm{m}$ mesh size weighed down by a $2 \mathrm{~kg}$ depressor. An angle meter was used to calibrate the towing speed and net depth, which varied depending on the direction and speed of the currents at the time of survey $\left(2-4 \mathrm{~km} \mathrm{~h}^{-1}\right)$. The volume of water passing through each net was obtained from flowmeters (Hydrobios) attached to each net opening. Plankton samples were preserved in $100 \%$ ethanol for molecular analyses purposes. Larvae were identified, counted and measured under a dissecting scope (Olympus SZX7) with camera (Qimaging Micropublisher CCD). At the end of each transect a probe (HACH HQ 40d) was lowered $20 \mathrm{~m}$ and values of temperature and salinity were recorded every $2 \mathrm{~m}$ intervals. At most sites and occasions plankton tows were performed during day hours, but off Cumberland bay plankton was also collected at night within the next few hours (11 PM-2AM) of the respective diurnal samples (Table 1). The most general perspective on larval abundance and distribution was achieved when, in five occasions within the same day, all five sites around the island were visited and day-time plankton surveys were performed. A more localized effort, yet more frequent corresponded to the 20 and 13 plankton transects performed during day and night hours, respectively, off Cumberland bay between October 2008 and March 2011 (Table 1).

\section{Near-shore hydrography analyses}

We quantified the nearshore currents at different depths as well as wind pattern at fixed points near Cumberland bay during the first months of 2010 (view location of sensors in Fig. 1). Two Falmouth Scientific 3-D acoustic current meters were installed on a mooring system at a place where water depth was $30 \mathrm{~m}$ (100 m from shore). One meter was attached to the mooring line below the surface (2-3 m deep) and the second at $10 \mathrm{~m}$ below the surface. Both instruments were programmed to record current direction and speed every $10 \mathrm{~min}$. The weather station (onset microweather station with a Young wind probe) was installed on a nearby summit $400 \mathrm{~m}$ above sea level (see Fig. 1), which registered wind speed and direction every $10 \mathrm{~min}$. Wind speed records were re-calculated at $10 \mathrm{~m}$ above sea level according with standard methodology following to Large \& Pond (1981). We analyzed the wind and current information using progressive vectors, which depict the main flow tendencies for the wind and currents at different depth between February 12 and March 3 of 2010.

\section{Molecular analyses}

\section{Nucleotide sequence and phylogenetic analyses}

DNA was extracted from ethanol (100 \%) preserved samples from 12 adult muscle leg tissues using the Wizard Genomic DNA Purification Kit (http://www. promega.com/), whereas for the 18 larvae we used standard phenol/chloroform extraction protocols (Hillis et al. 1990). Two adults were samples from Robinson Crusoe Island, and the other 10 adults were from Desventuradas Islands. All larvae are from Robinson Crusoe Island and for DNA extraction we used the complete specimen. Primers used to amplify the $16 \mathrm{~s}$ were L2510 and H3080 (Palumbi 1996), and the thermal profile was performed using the following protocol: initial denaturation for $4 \mathrm{~min}$ at $94{ }^{\circ} \mathrm{C}$, followed by 30 cycles of $94{ }^{\circ} \mathrm{C}(30 \mathrm{~s}), 53{ }^{\circ} \mathrm{C}(10 \mathrm{~s})$, and $72{ }^{\circ} \mathrm{C}(30$ s). A final extension at $72{ }^{\circ} \mathrm{C}$ for $4 \mathrm{~min}$ terminated the reaction. Double-stranded PCR products were purified with Qiaquik (http://www.qiagen.com/). Cycle sequencing was performed using both PCR primers labeled with the Big Dye Terminator kit (Perkin Elmer, Norwalk, Connecticut). Sequencing reactions were

\section{TABLE 1}

Months between 2008 and 2011 when plankton surveys took place at the different sites around Robinson Crusoe Island. (D) correspond to day-time and (N) to night-time surveys. Blank spaces mean that no survey took place. During some months more than one survey was performed which is indicated with numbers in parenthesis.

Meses, entre 2008 y 2011, en los que se realizaron muestreos de plancton en los distintos sitios alrededor de la Isla Robinson Crusoe. (D) corresponde a muestreos diurnos y (N) a muestreos nocturnos. Espacios en blanco significan que no se realizaron muestreos. En algunos meses se realizaron más de un muestreo, lo que se indica con números entre paréntesis.

\begin{tabular}{lcccccccccccc}
\hline & & 2008 & & 2009 & & & & 2010 & & 2011 & \\
\hline Site & Nov & Dec & Feb & Mar & Dec & Jan & Feb & May & Jun & Nov & Jan & Mar \\
Cumberland & $\mathrm{D}(2)$ & $\mathrm{D} / \mathrm{N}$ & $\mathrm{D}(2)$ & $\mathrm{D}(3) / \mathrm{N}$ & $\mathrm{D}(2) / \mathrm{N}$ & $\mathrm{D}(4) / \mathrm{N}(4)$ & $\mathrm{D} / \mathrm{N}$ & $\mathrm{D} / \mathrm{N}$ & $\mathrm{D} / \mathrm{N}$ & $\mathrm{D} / \mathrm{N}$ & $\mathrm{D} / \mathrm{N}$ & $\mathrm{D} / \mathrm{N}$ \\
Bahia Padre & & & & $\mathrm{D}(2)$ & $\mathrm{D}$ & $\mathrm{D}(2)$ & & & & & & \\
Tres Puntas & & & & $\mathrm{D}(2)$ & $\mathrm{D}$ & $\mathrm{D}(2)$ & & & & & & \\
Tierras & & & & $\mathrm{D}(2)$ & $\mathrm{D}$ & $\mathrm{D}(2)$ & & & & & & \\
Blancas & & & & & & & & & & & & \\
Villagra & & & $\mathrm{D}(2)$ & $\mathrm{D}$ & $\mathrm{D}(2)$ & & & & & & \\
\hline
\end{tabular}


analyzed on an Applied Biosystems Prism 3100 (http:// www.appliedbiosystems.com/absite/us/) automated sequencer. Sequences were aligned using the CLUSTAL X program (Thompson et al. 1997) and by eye. All sequences have been deposited in GenBank under accession numbers JN566193-JN566222.

Phylogenetic analyses were conducted using maximum parsimony and maximum likelihood as implemented in PAUP* 4.0 b10 (Swofford 2002), and the tree was rooted with the outgroup criterion using Jasus edwardsii and Jasus lalandii. For maximum parsimony (MP) we treated all characters as unordered with four possible states (A, C, G, T) using only those characters that were phylogenetically informative. For parsimony, a heuristic search was performed with 100 random additions and branch swapping via treebisection-reconnection (TBR; Nei \& Kumar 2000). A strict consensus tree was estimated when more than one equally parsimonious tree was obtained, and we obtained the consistency index (CI) and the retention index (RI) for the most parsimonious tree. The reliability of nodes was estimated by nonparametric bootstrapping (Felsenstein 1985) with 1000 pseudoreplications. We selected the best-fitting model of nucleotide substitution using the Akaike Information Criterion (AIC; Akaike 1974) in Modeltest. We evaluated support for the nodes with 1000 bootstrap replicates (Felsenstein 1985). The AIC identified the HKY $+\Gamma$ model (Hasegawa et al. 1985) as the best model of base substitution. The gamma shape parameter was $=0.1689$, and the proportions of nucleotides were $\mathrm{A}=0.2980, \mathrm{C}=0.1643, \mathrm{G}=0.2301$, and $\mathrm{T}=0.3075$. For likelihood we performed a heuristic search with 10 random additions and branch swapping via TBR. The reliability of nodes for the likelihood tree was evaluated by 1000 pseudoreplicates.

\section{Statistical analysis}

In the case of larval abundance, we employed a non-parametric approach because of the nature of the dataset (many zeros but also some values of higher magnitude, which represents an unknown data frequency distribution). These analyses were performed to evaluate differences between samples. The KruskalWallis test was used for comparing the abundance of each species at the five sites around the island. The Mann-Whitney U-test was utilized for the comparisons between the abundance present at night vs. day samples and also for those collected at $10 \mathrm{~m}$ vs. at the surface. We examined the use of parametric tools such as zeroinflated Poisson models, but model fits proved poorer than the more simple non-parametric approach (results not shown).

In order to illustrate the association of environmental variables (temperature and salinity) with the abundance of larvae in the water column, Hovmoller plots (time vs. depth) were constructed with Surfer 10 software using Kriging interpolation for environmental variables and overlaying abundance data (ind. $100 \mathrm{~m}^{-3}$ ). In order to explore the association between these environmental factors and larval abundance we utilized the average values of the upper $20 \mathrm{~m}$ of the water column. Thus, we studied the relationship between sea surface salinity (SSS) and sea surface temperature (SST) with that of larval abundance through a Spearman rank correlation analysis $\left(r_{s}\right)$. The analysis considered the data obtained from October 2008 to march 2011. A significance level of $\mathrm{P} \leq 0.05$ was considered throughout the study.

\section{RESULTS}

\section{Larval distribution and abundance}

Based on information obtained from cultured individuals (Dupré \& Guisado 1996) and larval descriptions (Báez 1973) all phyllosoma found throughout this study (69 and 376 individuals, $J$. frontalis and $A$. delfini, respectively), at least for $J$. frontalis, corresponded to the first four stages, with an average carapace width size of $1.78 \pm 0.25 \mathrm{~mm}$ (individuals ranged from 1.44 to $2.80 \mathrm{~mm}$ ). On the other hand, no such referential information is available for $A$. delfini, however, given their small average size $(1.36 \pm$ $0.38 \mathrm{~mm}$ ), yet broader spectrum of size range ( 0.9 to $5.5 \mathrm{~mm}$ ), we could infer that our surveys captured a broader range of larval stages.

The distribution and abundance of larvae around the island during day-time surveys exhibited a different pattern for the two species. Phyllosoma of $J$. frontalis were less abundant than those of $A$. delfini collected in the same locations at the same time (Fig. 2A). The former species was significantly more abundant at the two northern sides of the island (Cumberland and Tres Puntas bays) at the two depths considered (surface: $\mathrm{H}=11.58, \mathrm{df}=4, \mathrm{~N}=71$, $\mathrm{P}<0.05$; and $10 \mathrm{~m}: \mathrm{H}=15.64, \mathrm{df}=4, \mathrm{~N}=71, \mathrm{P}<$ 0.01 ). While more abundant than $J$. frontalis, $A$. delfini exhibited comparable numbers at most sites around the island (Fig. 2B) and significant differences among sites were only detected for samples collected at the surface (surface: $\mathrm{H}=9.85, \mathrm{df}=4, \mathrm{~N}=71, \mathrm{P}<0.05$ and $10 \mathrm{~m}: \mathrm{H}=$ $7.70, \mathrm{df}=4, \mathrm{~N}=71, \mathrm{P}=0.1032)$. What appears to represent a pattern of higher abundance of larvae at $10 \mathrm{~m}$ than those found at the surface (Fig. 2A and 2B) is further investigated with the more frequent surveys off Cumberland bay (see below).

Locally, the distribution and abundance of larvae of the two species, obtained from repeated visits to the same transect off Cumberland bay (the only site visited in repeated occasions between 2008 and 2011, see Table 1), exhibits a pattern of great variability throughout $>2$ years of surveys (Fig. 3A and $3 \mathrm{C})$. While the water column between the surface and $20 \mathrm{~m}$ exhibited a clear seasonal pattern given the changes in temperature and salinity, it did not show signs of vertical stratification (Fig. 3). Temperature showed a 
strong seasonal variability, ranging from $14{ }^{\circ} \mathrm{C}$ in the winter (May-June) up to $20{ }^{\circ} \mathrm{C}$ during spring-summer (November-March). In the case of salinity it varied between 25 and $34 \mathrm{psu}$, with lower values during fall-winter months (May-June) and greater during spring-summer months (November-March). Throughout phyllosomas of $J$. frontalis were significantly more abundant at $10 \mathrm{~m}$ than at the surface $(\mathrm{U}$ $=5, \mathrm{P}=0.022, \mathrm{~N}=6$ and 7 at $10 \mathrm{~m}$ and surface, respectively) and also during night-time surveys at both depths $(\mathrm{U}=11, \mathrm{P}=0.014, \mathrm{~N}=6$ and 13 at night and day, respectively) (Fig. 3A). The same pattern was displayed by $A$. delfini, with individuals at $10 \mathrm{~m}$ being significantly more abundant $(\mathrm{U}=48, \mathrm{P}=0.007, \mathrm{~N}=21$ and 11 at $10 \mathrm{~m}$ and surface, respectively) as well as night

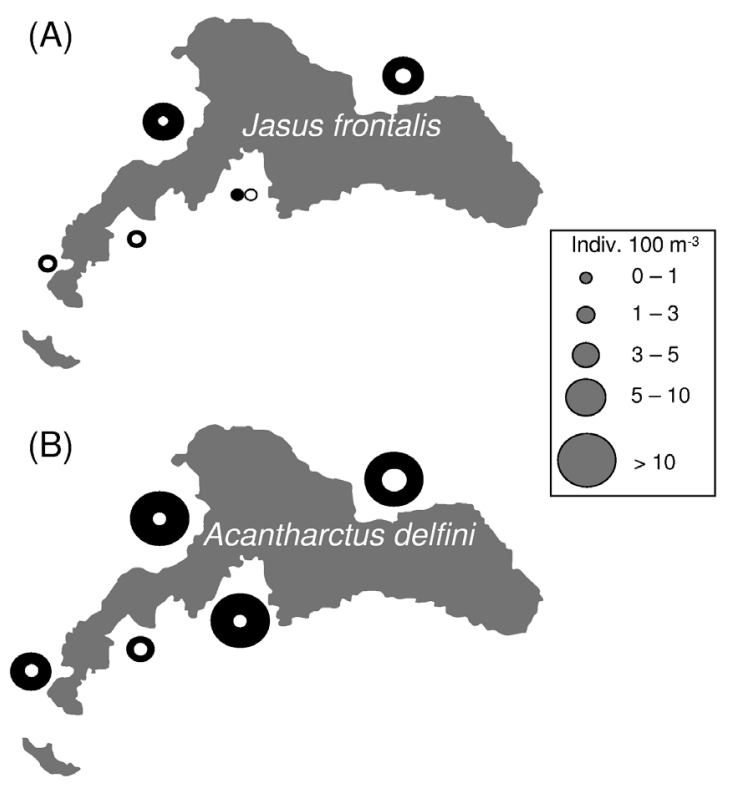

Fig. 2: Average number of phyllosoma $100 \mathrm{~m}^{-3}$ of (A) Jasus frontalis and (B) Acantharctus delfini, at different sites around Robinson Crusoe obtained from 5 replicated plankton tows performed during daytime at each site only during the spring-summer months between December 2008 and January 2010. Black circles correspond to $10 \mathrm{~m}$ tows and white circles (within) to surface tows.

Número promedio de filosomas $100 \mathrm{~m}^{-3}$ de (A) Jasus frontalis and (B) Acantharctus delfini, en diferentes sitios alrededor de la isla Robinson Crusoe obtenidos a partir de 5 arrastres replicados de plancton diurnos realizados en cada sitio solo durante los meses de primavera-verano entre diciembre 2008 y enero 2010. Círculos negros corresponden a muestreos a 10 $\mathrm{m}$ y círculos blancos (interiores) a muestreos superficiales. hours compared with day-time surveys $(\mathrm{U}=$ $72, \mathrm{P}=0.004, \mathrm{~N}=11$ and 32 at night and day, respectively) (Fig. 3C).

When correlations between physical variables and the abundance of larvae were explored, we found that in the case of $J$. frontalis neither temperature nor salinity showed a significant relationship with larval abundance $\left(r_{\mathrm{s}}\right.$ SST $=-0.038, \mathrm{P}=0.874 ; \mathrm{r}_{\mathrm{s}} \mathrm{SSS}=0.313, \mathrm{P}=$ 0.191 ), although the trend was to find larvae in saltier waters of intermediate temperatures (Fig. 3B). On the other hand, A. delfini exhibited a statistically significant preference $\left(r_{\mathrm{s}} \mathrm{SST}=0.336, \mathrm{P}<0.05 ; \mathrm{R}_{\mathrm{s}} \mathrm{SSS}=0.511, \mathrm{P}\right.$ $<0.05)$ for warm waters with high salinity (Fig. 3D). A significance value of $\mathrm{P}=0.05$ was considered throughout.

\section{Near-shore hydrography analyses}

The progressive vector analysis describes the Eulerian trajectory of wind and currents near the surface and at $10 \mathrm{~m}$ depth. Our two weeklong window of observation exhibits a fairly steady wind direction to the north-west while currents flow in different directions at each depth (Fig. 4). While water at $10 \mathrm{~m}$ follows a south-east direction, that matches the coast line contour at this point, the surface water has an average flow to the south-west, displaying changes in direction at higher frequencies, most likely due to the effect of tides. Even though the current and wind data shown do not pair in time with plankton data they were obtained within one of the same summer field seasons. Results support the presence of distinctive circulation patterns in the upper layers of the water column nearshore.

\section{Molecular analyses and larval identification}

Maximum parsimony analysis recovered equal parsimonious trees 106 steps length, consistency index $(\mathrm{CI})=0.9623$ and retention index $(\mathrm{RI})=0.9937$. Both analyses (parsimony and likelihood) recovered the same topology (Fig. 5) in which a strong differentiation is shown within some of the larvae samples suggesting intraspecific diversification. The bootstrap support for that split was 100 percent. The larval samples from these two branches were carefully examined under the dissecting scope and it was possible to distinguish two 

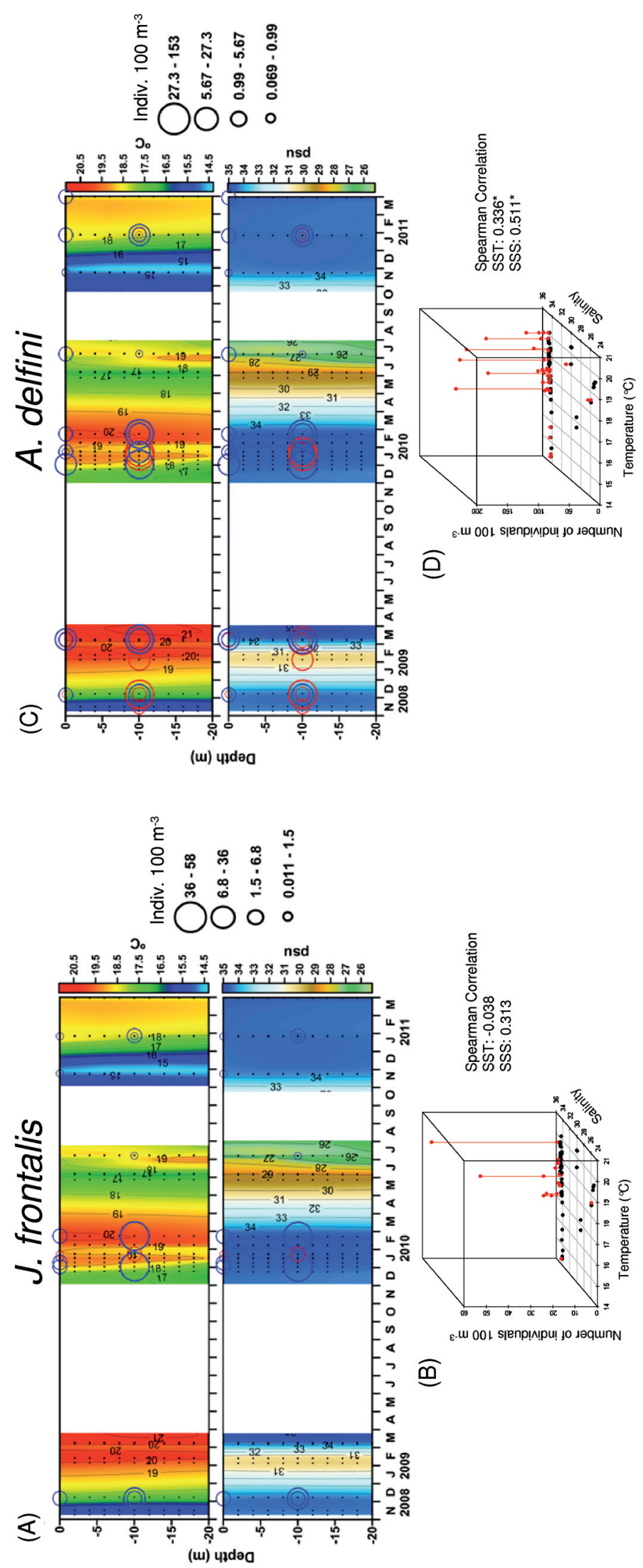

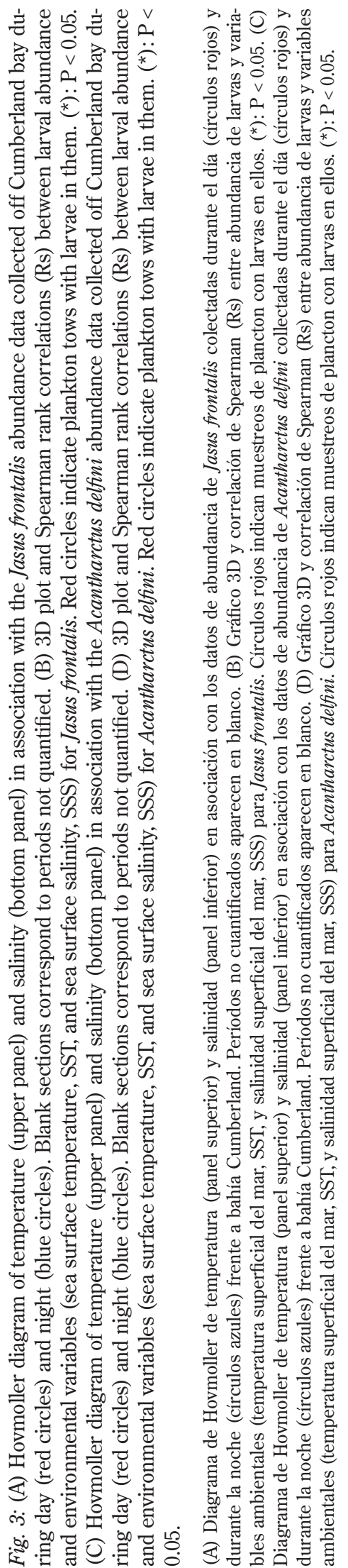




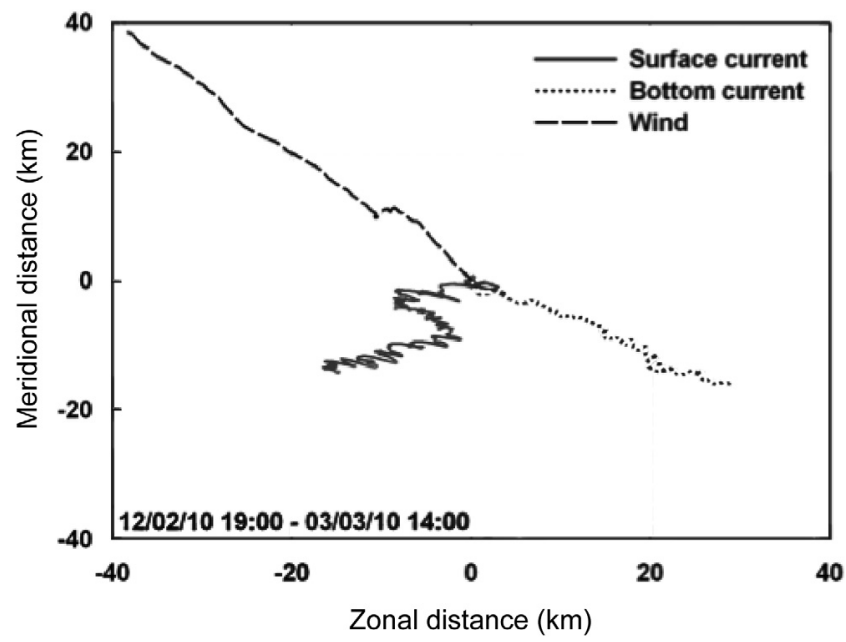

Fig. 4: Progressive vector diagram for the period February 12 and March 3 of 2010 showing the direction of wind and currents (at $2 \mathrm{~m}$ and $10 \mathrm{~m}$ below the surface) measured with weather station and two acoustic current meters affixed to a mooring located along the shore $2 \mathrm{~km}$ west of Cumberland bay.

Diagrama de vector progresivo para el período comprendido entre Febrero 12 y Marzo 3 de 2010 que muestra la dirección del viento y corrientes (a $2 \mathrm{~m}$ y $10 \mathrm{~m}$ bajo la superficie) medidos mediante una estación meteorológica y dos correntómetros acústicos fijos a un fondeo localizado a lo largo de la costa a $2 \mathrm{~km}$ al oeste de la Bahía Cumberland

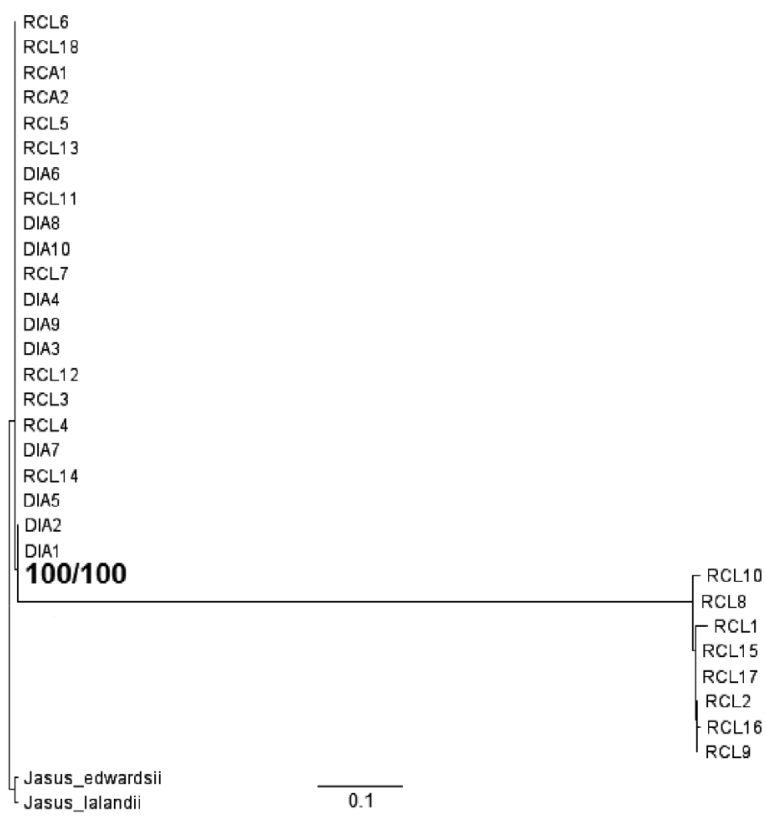

Fig. 5: Maximum parsimony and maximum likelihood tree based on 30 sequences of the 16S rRNA mitochondrial gene on samples originally identified as Jasus frontalis according to morphological data. Acronyms of samples in the tree correspond to: RCL (Robinson Crusoe larvae), RCA (Robinson Crusoe adult), DIA (Desventuradas Islands adult). Outgroups correspond to J. edwardsii and J. lalandii, two congeneric species from the south west Pacific and off the coast of southern Africa, respectively.

Árbol de máxima parsimonia y máxima verosimilitud basado en 30 secuencias de gen mitocondrial $16 \mathrm{~S}$ rRNA a partir de muestras originalmente identificadas como Jasus frontalis de acuerdo a datos morfológicos. Los acrónimos de las muestras en el árbol corresponden a: RCL (larvas Robinson Crusoe), RCA (adultos Robinson Crusoe), DIA (adultos Islas Desventuradas). Los outgroups corresponden a J. edwardsii y J. lalandii, dos especies congenéricas del Pacífico sur occidental y frente a la costa sur de África, respectivamente. 
easy-to-spot anatomical features that separate $J$. frontalis from $A$. delfini. The antenna in the former is as long as the antennule (which presents a bifurcation towards the distal end) while in the later the antenna is much longer than the antennule.

\section{DISCUSSION}

Our biologic and geographic system is comparable to others where organisms (i.e. reef fish in the Caribbean) are endemic in spite of having a dispersive larval phase (Robertson 2001). Biophysical models considering larval behavior and ocean currents have been used to show that larvae can stay closer to their places of origination than previously thought (Robertson 2001, Cowen et al. 2000, Cowen et al. 2006). In this study we centered our attention in understanding the distribution and abundance of phyllosoma (Jasus frontalis and Acantharctus delfini) as a contribution to our understanding of the mechanisms maintaining their endemism in the Juan Fernández archipelago. Most previous initiatives regarding the study of plankton around this island have corresponded to brief visits that collected valuable yet scattered information (i.e. Rivera \& Mujica 2004, Mujica 2006). This study is unique in that larval surveys were performed on a frequent basis, over a period of $>2$ years, very near the coast and included the simultaneous use of two different nets covering the top 10 $\mathrm{m}$ of the water column. In one of the sites around the island (off Cumberland bay) larval tows were also performed during day and night hours. The general justification behind the nearshore sampling scheme obeyed to the fact that adults of these two lobster species only occur along coastal settings of these few islands with steep coastal bathymetry (Báez 1973), therefore the release of larvae and their subsequent return has to be coastal. The close resemblance of the phyllosoma of these species, therefore difficult to identify, was solved thanks to the molecular approach pursued in this study. These results allowed us to unambiguously recognize the two species following specific anatomical features of the antenna and antennule.

Most previous studies regarding the distribution of phyllosomas broadly suggest that newly-hatched larvae of most species of spiny lobsters first rise to the surface and later migrate vertically between the surface at night and deeper waters during the day as they are carried offshore (Phillips \& Sastry 1980). However, it is noticeably that most of those studies (e.g., Booth \& Phillips 1994, Chiswell \& Roemmich 1998, Chiswell \& Booth 2005) focus on large spatial-scale pattern of widely distributed species of lobsters, lacking insight into processes likely to drive the larval ecology of species like $J$. frontalis and A. delfini, endemic to a small island system.

After over two years of surveys, with most visits during the spring-summer months, although some additional surveys also covered the remaining seasons, we could draw a generalized pattern in which phyllosomas of the two species were present at all sites around the island. On a closer look, however, $J$. frontalis occurred in greater numbers at the two northernmost sites (Tres Puntas and Cumberland bays) while, in general more abundant, $A$. delfini was evenly distributed along those same sites. At the same island-scale both species were in general more abundant at the deeper strata $(10 \mathrm{~m})$. At least for $J$. frontalis all individuals found, corresponded to earlier larval stages; a conspicuous pattern given that phyllosoma of this species can reach a total length 10 times those found in our study (Mujica et al. 2010). On the other hand, the broader size spectrum exhibited throughout by $A$. delfini suggests that we were able to capture more larval stages of this species at nearshore sites around the island. These patterns are similar to those found for several taxa by Morgan \& Fisher (2010) further suggesting that larvae (at least of early stages) are being retained near the coast.

The long data set of basic water column features (temperature and salinity) showed a strong seasonal signal that dominated the whole upper $20 \mathrm{~m}$ of the water column at any given time. This clearly shows that the island is affected by distinctive water masses at different times, which agrees with the general oceanographic descriptions for this part of the south east Pacific (Fuenzalida et al. 2007, Schneider et al. 2007, Moraga $\&$ Argandoña 2008). Some authors have even suggested that these seasonal changes, resulting from alternate northward and 
southward circulation conditions, are the way in which larvae are being maintained within the system encompassing the Desventuradas and the Juan Fernández archipelagos (Rivera $\&$ Mujica 2004). While the former could be the case, there is no evidence yet on the nature of smaller-scale mechanisms maintaining the larvae within this system. Unfortunately, the sparse nature of our larval collection (we could only visit the island in certain periods) prevented us from exploring their potential seasonality. There is a growing amount of literature, however, showing results wherein larval behavior (mainly vertical migration) is a key aspect keeping larval stages near their adult benthic environment (e.g., Shanks \& Eckert 2005, Morgan 2006, Morgan \& Fisher 2010).

While both species were significantly more abundant at night at any depth surveyed, they also tended to be more abundant at $10 \mathrm{~m}$ at any given time. Although we know that larvae of these species can be found at greater depths (> 10 m, Rivera \& Mujica 2004, Mujica 2006) we still were able to capture the signal of their vertical displacement. Such active diurnal vertical migration, novel for $J$. frontalis and $A$. delfini, is common among several other meroplanktonic larvae, and it has been related, for example, to nearshore retention of larvae with coastal adult populations (e.g., Forward et al. 1996, Shanks 1986) and also to the avoidance of predators (e.g., Ohman et al. 1983, Richards et al. 1996). In some cases larvae perform daily vertical migrations that, in combination with contrasting flows at different depths, result in larvae being advected toward the coast (i.e. Poulin et al. 2002a, 2002b) or retained near the coast by staying at layers of the water column that are not advected offshore (Morgan \& Fisher 2010). While we cannot rule out any of these hypotheses, and given the endemism status of these species, their ubiquitous short-term spatial and temporal patterns of distribution suggest the possibility of some type of circulation system that would favor nearshore larval retention. For several Scyllaridae species with comparable short larval phase duration, likely to be the case of $A$. delfini, it has been shown how all the larval stages are retained in nearshore waters while only early and final larval stages of Palinuridae remain in the same waters (Inoue et al. 2001). The latter description resembles the broad larval size spectrum exhibited by $A$. delfini and the narrow one for $J$. frontalis over an extended period of time. Our quantifications of wind and currents at different depths represents additional evidence that the nearshore system of Robinson Crusoe Island presents conditions of contrasting flow at different depths, which linked to the vertical movement displayed by these species, could likely favor the retention near the coast of vertically migrating larvae.

Hence, although further research is necessary, we suggest that these species are capable of coupling their vertical migration behavior with the local circulation dynamics present in the nearshore system off Robinson Crusoe Island. This may be useful to depict the retention conditions, processes and mechanisms behind the endemism of species that have yet, the potential for wide range dispersal.

ACKNOWLEDGEMENTS: We dedicate this work to our late friend and colleague Paulita "Poli" Ayerdi who perished during the tsunami that struck Robinson Crusoe Island on February 27th 2010 . We also want to thank all the students and research assistants that participated at different stages of this research. Special thanks to Miguel Rojas and family, Ignacio Maturana, Marcelo Rossi, Gerardo Velazquez "Capi”, Ramón Baeza, Rudy Aravena, Ricardo Cancino and Ramiro Riquelme-Bugueño among many others that helped in so many ways. Comments by two anonymous reviewers guided significant improvements to the manuscript. This research was supported by grants: FONDAP 1501-001, FONDECYT 1080009 and NatGeo/Waitt to ATP and NSF OCE-1039822 to Richard Wahle \& Peter Petraitis.

\section{LITERATURE CITED}

AKAIKE H (1974) A new look at the statistical model identification. IEEE Transactions on Automatic Control 19: 716-723.

ARANA P (1985) Análisis y recomendaciones sobre las medidas de regulación en la pesquería de la langosta de Juan Fernández (Jasus frontalis). En Investigaciones marinas en el Archipiélago de Juan Fernández, P. Arana (ed): 291-300. Escuela de Ciencias del Mar, Universidad Católica de Valparaíso, Valparaíso, Chile.

ARANA P (ed) (1987) Perspectivas históricas y proyecciones de la actividad pesquera realizada en el archipiélago de Juan Fernández, Chile. Islas oceánicas chilenas: Conocimiento científico y necesidades de investigaciones. Ediciones Universidad Católica de Chile, Chile.

ARANA P \& C MELO (1973) La langosta de Juan Fernández. II. Pesca comercial de Jasus frontalis en las islas de Robinson Crusoe y Santa Clara (1971-1972). Investigaciones marinas, 4: 135-154.

ARANA P \& R VEGA (2000) Esfuerzo captura y captura por unidad de esfuerzo en la pesquería de la 
langosta de Juan Fernández (Jasus frontalis), durante la temporada de pesca 1996-1997. Investigaciones Marinas 28: 117-133.

BÁEZ P (1973) Larvas Phyllosoma del Pacífico sur oriental (Crustacea, Macrura, Scyllaridae). Revista de Biología Marina 15: 115-130.

BOOTH JD \& BF PHILLIPS (1994) Early life history of spiny lobster. Crustaceana 66: 271-294.

BOOTH JD, WR WEBBER, H SEKIGUCHI \& E COUTURES (2005) Diverse larval recruitment strategies within the Scyllaridae. New Zealand Journal of Marine and Freshwater Research 39: 581-592.

BRUCE B, R BRADFORD, D GRIFFIN, C GARDNER \& J YOUNG (2000) A synthesis of existing data on larval rock lobster distribution in Southern Australia. Final Report. Project N0. 96/107. Fisheries Research and Development Corporation. Australia.

CARLON DB \& RR OLSON (1993) Larval dispersal distance as an explanation for adult spatial pattern in two Caribbean reef corals. Journal Experimental Marine Biology and Ecology 173: 247-263.

CHISWELL SM \& D ROEMMICH (1998) The East Cape Current and two eddies: A mechanism for larval retention? New Zealand Journal of Marine and Freshwater Research 32: 385-397.

CHISWELL SM \& JD BOOTH (2005) Distribution of mid- and late-stage Jasus edwardsii phyllosomas: implications for larval recruitment processes. New Zealand Journal of Marine and Freshwater Research 39: 1157-1170

COUTURES E (2000) Distribution of Phyllosoma larvae of Scyllaridae and Palinuridae (Decapoda: Palinuridae) in the south-western lagoon of New Caledonia. Marine and Freshwater Research 51: 363-369.

COWEN RK, M KAMAZIMA, M LWIZA, S SPONAUGLE, CB PARIS \& DB OLSON (2000). Connectivity of marine populations: open or closed? Science 287: 857-859.

COWEN RK, CB PARIS \& A SRINIVASAN (2006). Scaling of connectivity in marine populations. Science 311: 522-527.

COWEN RK (2002) Oceanographic influences on larval dispersal and retention and their consequences for population connectivity. In Ecology of coral reef fishes: Recent advances. P.F Sale (ed): 149179. Academic Press, San Diego. California.

DISALVO LH (1988) Observations on the larval and post-metamorphic life of Concholepas concholepas (Bruguiere, 1789) in laboratory culture. Veliger 30: 358-368.

DUPRÉ E \& A GUISADO (1996) Identificación de los primeros estados de phyllosoma de la langosta de Juan Fernández (Jasus frontalis) mantenidos en laboratorio. Investigaciones Marinas 24: 39-50.

ECKERT GL (2003) Effect of the planktonic period on marine population fluctuations. Ecology 84: 372383.

FELSENSTEIN J (1985) Confidence limits on phylogenies: An approach using bootstrap. Evolution 39: 783-791.

FORRESTER GE (1995) Strong density-dependent survival and recruitment regulate the abundance of a coral reef fish. Oecologia 103: 275-282.

FORWARD RB JR, MC DE VRIES, D RITTSCHOF, DAZ FRANKEL, JP BISCHOFF, CM FISHER \& JM WELCH (1996) Effects of environmental cues on metamorphosis of the blue crab Callinectes sapidus. Marine Ecology Progress Series 131:165177.

FUENZALIDA R, W SCHNEIDER, J BLANCO, J GARCÉS \& L BRAVO (2007) Sistema de corrientes Chile-Perú y masas de agua entre Caldera e Isla de Pascua. Ciencia y Tecnología del Mar 30: 5-16.

HASEGAWA M, H KISHINO \& T YANO (1985) Dating of the human-ape splitting by a molecular clock of mitochondrial DNA. Journal of Molecular Evolution 21: 160-174

HILLIS DM, B K MABLE, A LARSON, SK DAVIS \& EA ZIMMER (eds) (1990) Nucleic acids IV: Sequencing and cloning. In: Molecular Systematics. Second edition. Massachusetts.

HOLTHUIS LB (2002) The Indo-Pacific scyllarine lobsters (Crustacea, Decapoda, Scyllaridae). Zoosystema 24: 499-683.

INCZE LS, RA WAHLE \& AT PALMA (2000) Advection and settlement rates in a benthic invertebrate: Recruitment to first benthic stage in Homarus americanus. ICES Journal of Marine Science 57: 430-437.

INOUE N, H SEKIGUCHI \& S-P YEH (2001) Spatial distribution of phyllosoma larvae (Crustacea: Decapoda: Palinuridae, Scyllaridae) in Taiwanese waters. Journal of Oceanography 57: 535-548.

LARGE WG \& S POND (1981) Open ocean momentum flux measurements in moderate to strong winds. Journal of Physical Oceanography 11: 324-481.

BORÉ D \& C MARTÍNEZ (eds)(1980) Catálogo de recursos pesqueros Chile. CORFO-IFOP, Corporación de Fomento de la Producción, Instituto de Fomento Pesquero. Santiago, Chile.

MINCHINTON TE \& RE SCHEIBLING (1991) The influence of larval supply and settlement on the population structure of barnacles. Ecology 72: 1867-1879.

MORA C \& PF SALE (2002) Are populations of coral reef fish open or closed? Trend in Ecology and Evolution 17: 422-428.

MORAGA J \& W ARGANDOÑA (2008) Oceanographic conditions around the archipelago Juan Fernández and San Felix-San Ambrosio islands. Ciencia y Tecnología del Mar 31: 137-148.

MORGAN SG (eds) (2006) Larval migration between the Hudson River estuary and New York Bight. Cambridge University Press, New York.

MORGAN SG \& JF FISHER (2010) Larval behavior regulates nearshore retention and offshore migration in an upwelling shadow and along the open coast. Marine Ecology Progress Series 404: 109-126.

MUJICA A (2006) Larvas de crustáceos decápodos del archipiélago Juan Fernández ( $33^{\circ} 40^{\prime} \mathrm{S}-78^{\circ} 50^{\prime}$ W) e islas Desventuradas $\left(26^{\circ} 20^{\prime} \mathrm{S}-80^{\circ} 05^{\prime} \mathrm{W}\right)$. Ciencia y Tecnología del Mar 29: 137-152.

MUJICA A, ML NAVA \& E FLORES (2010) Phyllosoma de Jasus frontalis (Decapoda: Palinuridae) en la costa continental de Chile. Revista de Biología Marina y Oceanografía 45: 347-351.

NEI M \& S KUMAR (eds) (2000) Molecular Evolution and Phylogenetics. Oxford University Press, USA

OHMAN MD, BW FROST \& EB COHEN (1983) Reverse diel vertical migration: An escape from invertebrate predators. Science 220: 1404-1407.

PALMA AT, LM PARDO, R VEAS, C CARTES, M SILVA, K MANRÍQUEZ, A DIAZ, C MUÑOZ, \& FP OJEDA (2006) Coastal brachyuran decapods: 
Settlement and recruitment under contrasting coastal geometry conditions. Marine Ecology Progress Series 316: 139-153.

PALUMBI SR (ed)(1996) Nucleic acids II: The polymerase chain reaction. In: Molecular Systematics. Second edition, Massachusetts.

PARÍN N, A MIRONOV AND K NESIS (1997) Biology of the Nazca and Salas y Gómez Submarine ridges, an out post of the Indo-West Pacific fauna in the eastern Pacific Ocean: Composition and distribution of the fauna, its communities and history. Advances in Marine Biology 32: 145-242.

PARIS CB \& RK COWEN (2004). Direct evidence of a biophysical retention mechanism for coral reef fish larvae. Limnology \& Oceanography 49: 19641979.

PHILLIPS BF \& SASTRY AN (1980) Larval ecology. In: JS Cobb and BF Phillips(eds), The biology and management of lobsters, vol. 2: Ecology and Management, New York.

PHILLIPS BF, JD BOOTH, JS COBB, AG JEFFS \& P MCWILLIAM (2006) Lobsters, Biology, Management, Aquaculture and Fisheries. In: BF Phillips (eds) Chapter 7: Larval and postlarval ecology: 231-262. Oxford.

POULIN E, AT PALMA, G LEIVA, D NARVÁEZ, R PACHECO, S A NAVARRETE \& JC CASTILLA (2002) Avoiding offshore transport of competent larvae during upwelling events: the case of the gastropod Concholepas concholepas in Central Chile. Limnology \& Oceanography 47:1248-1255

POULIN E, AT PALMA, G LEIVA, E HERNÁNDEZ, P MARTÍNEZ, S NAVARRETE \& JC CASTILLA (2002) Temporal and spatial variation in the distribution of premetamorphic larvae of Concholepas concholepas (Gastropoda: Muricidae) along the central coast of Chile. Marine Ecology Progress Series 229: 95-104.

RICHARDS SA, HP POSSINGHAM \& J NOYE (1996) Diel vertical migration: Modeling light-mediated mechanisms. Journal of Plankton Research 18: 2199-2222.

RIVERA J \& A MUJICA (2004) Larvas phyllosoma (Decapoda, Palinuridae y Scyllaridae) de las islas oceánicas chilenas. Investigaciones Marinas 32: 99-111.

ROBERTSON DR (2001) Population maintenance among tropical reef fishes: Inferences from small island endemics. Proceedings of the National Academy of Sciences USA 98: 5667-5670.

SCHELTEMA RS (1975) Chemistry, biology and the Estuarine System. In: Estuarine Research (eds) Vol. 1: Relationship of larval dispersal, gene-flow and natural selection to geographic variation of benthic invertebrates in estuaries and along coastal regions: 372-391. New York.
SCHELTEMA RS (1986) Long-distance dispersal by planktonic larvae of shoal-water invertebrates among central Pacific Islands. Bulletin of Marine Sciences 39: 241-256.

SHANKS AL, BA GRANTHAM \& MH CARR (2003) Propagule dispersal distance and the size and spacing of marine reserves. Ecological Applications 13: S159-S169.

SHANKS AL \& GL ECKERT (2005) Population persistence of California Current fishes and benthic crustaceans: A marine drift paradox. Ecological Monographs 75: 505-524.

SHANKS AL (1986) Vertical migration and cross-shelf dispersal of larval Cancer spp. and Randallia ornata (Crustacea: Brachyura) off the coast of southern California. Marine Biology 92: 189-199.

SCHNEIDER W, R FUENZALIDA, R NUNEZ, R BRAVO \& D FIGUEROA (2007) Discusión del sistema de la Corriente de Humboldt y masas de agua en la zona norte y centro de Chile. Ciencia y Tecnología del Mar 30: 21-36.

STENECK RS (2006) Staying connected in a turbulent world. Science 311: 480-481.

SWOFFORD DL (ed) (2002) PAUP*: Phylogenetic Analyses Using Parsimony (* and other methods). Version 4.0b10. Sinauer Associates, Inc., Publishers, Sunderland, Massachusetts.

THOMPSON JD, TJ GIBSON, F PLEWNIAK, F JEANMOUGIN, DG HIGGINS (1997) The CLUSTAL_X Windows interface: Flexible strategies for multiple sequence alignment aided by quality analysis tools. Nucleic Acids Research 25: 4876-4882.

VERGARA H \& E MORALES (1985) Morfología submarina del segmento central del cordón asísmico Juan Fernández, Pacífico suroriental. En: Investigaciones marinas en el Archipiélago de Juan Fernández, P. Arana (ed): 25-34. Escuela de Ciencias del Mar, Universidad Católica de Valparaíso, Valparaíso, Chile.

WING SR, LW BOTSFORD, JL LARGIER \& LE MORGAN (1995) Spatial structure of relaxation events and crab settlement in the northern California upwelling system. Marine Ecology Progress Series 128: 199-211.

YÁÑEZ E, L PIZARRO, MA BARBIERI \& O BARRA (1985) Dinámica del stock de langosta (Jasus frontalis $\mathrm{H}$. Milne Edwards, 1837) explotado en el archipiélago de Juan Fernández $\left(33^{\circ} 40^{\prime} \mathrm{S}-80^{\circ}\right.$ W). In: Arana P (ed) Investigaciones marinas en el Archipiélago de Juan Fernández: 251-271. Escuela de Ciencias del Mar, Universidad Católica de Valparaíso, Valparaíso, Chile. 